\title{
WAYS OF EFFECTIVE DEVELOPMENT OF INNOVATIVE ACTIVITIES AT PRODUCTION ENTERPRISES OF THE REPUBLIC OF UZBEKISTAN
}

\author{
Raupova Nigora Djalolovna \\ Teacher of the Tashkent Textile Light Industrial Institute,100100, \\ Shohjaxon street 5, Tashkent city, Uzbekistan
}

Article DOI: https://doi.org/10.36713/epra5255

\begin{abstract}
In this article, special attention is paid to the problems of the development transfer of products and technologies in increasing the efficiency of innovative activity and methods of their elimination are proposed, aimed at increasing the efficiency of production, also the ways of effective development of innovative processes at manufacturing enterprises are proposed.
\end{abstract}

KEYWORDS: production, innovative development, innovative technologies, efficiency, technoparks, technopolises.

\section{DISCUSSION}

In a globalized world, the innovative development of industries and sectors is a priority in ensuring sustainable economic growth of the world and national economies. In economically developed countries, $70-90 \%$ of the gross domestic product is created precisely through the development of innovative activities. At the same time, the economy achieves high rates of development based on the introduction of scientific and technological and promising innovative techniques and technologies, useful and profitable innovations, modernization of leading industries, modern technical and technological update, and the introduction of local innovative technologies.

The experience of industrialized countries shows that the high innovative activity of the economy is ensured by the leading role of the state in the market of science and technology, the determination of national priorities, the active influence of the state on the process of innovative development through economic incentives.

The priority strategic direction of the innovative development of the economy of Uzbekistan is the creation of a national innovation mechanism, which is a system of organizational, economic and legal measures and the implementation of certain innovative projects. This system should ensure the production of new knowledge, the operational application of research results in the real sector of the economy and the sale of new products to consumers. In this regard, the effective development of innovation is of great importance, since the competitiveness of industrial enterprises of the republic as domestic

In this regard, the effective development of innovative activities is of great importance, since the competitiveness of industrial enterprises of the republic both in the domestic and foreign markets depends on the efficiency and effectiveness of its activities.

Research shows the need to form a balance between all the components and links of the innovation cycle to increase the innovative activity of industrial enterprises of the republic. One of these direction is the creation of mechanisms for the interaction of subjects directly implemented or participating in innovation in the production process. This creates demand for the effective formation of innovative activities at manufacturing enterprises and the creation of conditions for their development. The systematization of foreign experience in the formation and development of innovative activity allows us to identify the main, basic aspects of the 


\section{EPRA International Journal of Research and Development (IJRD)}

creation of some of its elements and to show the possibilities of their use in the national economy.

One of the most prospective foreign practices, from the point of view of the development of innovation activity and its directions, is the use of models with the participation of the private sector and research organizations. These models ensure the distribution of investment risks and savings in public funds in organizing innovative activities.

In our opinion, the mechanism for the development of innovative activities should be based on the following principles:

Ensuring coordinated communication of existing research institutes, industrial enterprises and credit and financial institutions;

Creation of a mechanism for ensuring coordination and sustainable interaction in the implementation of innovative activities at industrial enterprises;

Need to identify the long-term prospects for the innovative development of industrial enterprises;

Adaptation to the changing conditions of the external and internal environment and focus on the final result in the implementation of innovative activities in industrial enterprises.

The structure of innovation activity can include the following elements: educational institutions, research institutes, venture capital firms, engineering centers, techno parks, technopolises, business incubators, experimental certification centers, technology transfer centers, marketing centers, small innovation firms, databases intellectual property and others. Market factors are more influencing the development of decisions on the implementation of innovations in industrial enterprises, while the influence of subjective factors determines a more empirical approach to this process. All this indicates the low efficiency of innovative development of industrial enterprise.

Based on this, the industrial enterprises of the republic have sufficient potential for innovation, and in this regard, it is advisable to take the following measures: introduction of new equipment and technologies, diversification of production and application of new management methods; improvement systems of information support and communication to accelerate transfer of technology, the process of commercialization; Creation of an investment system and opportunities to stimulate innovative activity; improvement of mechanisms for the development of innovative activities at enterprises.

\section{LIST OF USED LITERATURE}

1. Ханкелдиева Г.Ш. Организационно экономический механизм управления инвестиционной деятельностью в сфере телекоммуникаџий //
Экономика и бизнес: теория и практика.2019. № 11-3.

2. Khankeldieva G.Sh. Prospects of the development of investment activity in the field of tourist services: problems and ways of solution // Theoretical \& Applied Science, Philadelphia, USA. 10, (78), 2019. 160-165 pp.

3. Khankeldieva G.Sh. Theoretical and Economic Prerequisites for the Development of Regional Industrial Clusters in the Economy of the Republic of Uzbekistan // EPRA International Journal of Research and Development (IJRD). 2020. pp. 234-240. https://doi.org/10.36713/epra 4855.

4. Хонкелдиева Г.Ш., Мамажонов Ж. Современная корпорачия: структура интересов основных корпоративных групп и проблема оиенки эффективности собственника. Наука сегодня фундаментальные и прикладные исследования: материалы международной конференции, С. 8283.

5. Ханкелдиева Г.Ш. Жизненный циикл корпорации и формирование приоритетов в реализации экономических интересов ее субъектов. Наука сегодня: опыт, традиции, инновачии: Материаль международной конференции, С. 46.

6. Features of Introducing Blockchain Technology in Digital Economy Developing Conditions in Uzbekistan $E$ Muminova, $G$ Honkeldiyeva, $K$ Kurpayanidi, S Akhunova, E3S Web of Conferences 159, 04023

7. Хонкелдиева, К., \& Фарохиддинова, 3. (2020). Оиенка влияния рынка труда на уровень безработищь в республике Узбекистан. Наука сегодня: факты, тенденции, прогнозы [Текст]: материа, 37.

8. Хонкелдиева, К., \& Фарохиддинова, 3. (2020). Гендерное равенство как иенность права. Наука сегодня: факты, тенденции, прогнозы [Текст]: материа, 61.

9. Хонкелдиева, К., \& Маматкулова, Ф. (2020). Социально-экономические аспекты устойчивого развития предприятия. In Наука сегодня: факты, тендениии, прогнозы (рр. 36-37).

10. Ханкелдиева Г. Ш. Особенности корпоративного управления в акционерных обществах $c$ государственным участием // Бюллетень науки и практики. Электрон. журн. 2017. №11 (24). С. 357-363. Режим доступа: http://www.bulletennauki.com/honkeldiveva (dama обращения 15.11.2017).

11. Ханкелдиева Г. Ш. Перспективы развития электроэнергетической отрасли Республики Узбекистан в условиях модернизации экономических отношений // Бюллетень науки и практики. Электрон. журн. 2017. №12 (25). С. 293-299. Режим доступа: http://www.bulletennauki.com/honkeldiveva-g (dama обрамения 15.12.2017). 